\title{
PEMBATASAN KONTEN DIGITAL PADA MEDIA NETFLIX OLEH KOMISI PENYIARAN INDONESIA
}

\author{
Ernawati \\ Magister Ilmu Hukum, Fakultas Hukum, Universitas Airlangga \\ e-mail: upettoke@gmail.com \\ Yemima Sonita Nugraheni \\ Magister Kenotariatan, Fakultas Hukum, Universitas Airlangga \\ e-mail: yemimanugraheni@gmail.com
}

\begin{abstract}
ABSTRAK
Rencana pengawasan terhadap konten digital yang disajikan oleh Youtube dan Netflix oleh Komisi Penyiaran Indonesia banyak ditentang oleh berbagai pihak. Netflix disini yang merupakan media baru dan KPI menganggap bahwa pengawasan terhadap media baru ini diperlukan, lantaran pada saat ini banyak masyarakat mulai pindah dari media konvensional seperti radio dan televisi ke media-media baru salah satunya netflix. Inovasi dari KPI ini selain ditentang oleh berbagai pihak, kewenangan untuk mengawasi media baru pun belum termasuk dalam cakupan tugas dan wewenang KPI. Isu yang diangkat pada penelitian ini adalah kedudukan KPI di dalam ketatanegaraan Indonesia dan kajian atas kewenangan KPI dalam membatasi konten digital media Netflix menurut UU No. 32 Tahun 2002. Metode penelitian yang digunakan dalam penelitian ini adalah yuridis normatif dengan pendekatan perundang-undangan dan pendekatan konseptual. Analisa atas isu hukum dengan menggunakan metode penelitian yang tepat, akan didapat konklusi bahwa dalam konteks perundang-undangan KPI belum berwenang untuk mengawasi media digital baru, sehingga diperlukan adanya revisi terutama mengenai konsep penyiaran, mengingat pengawasan media digital ini sudah menjadi hal yang penting untuk diperhatikan.
\end{abstract}

Kata Kunci: pengawasan; Komisi Penyiaran Indonesia; media digital

\section{ABSTRACT}

The Plan to monitor digital content such as that are presented by Youtube and Netflix by The Indonesian Broadcsting Commission is opposed by various parties. Netflix here is a new media and KPI assume that supervision of this new media is needed, because at this time many people are starting to switch from conventional media such as radio and television to new media, such as netflix. In addition to being opposed by various parties, this innovation of KPI has yet been included in the scope of duties and authority of KPI to oversee new media. The issues raised in this research are KPI's position in Indonesian state administration and a review of KPI's authority to restrict Netflix's digital media content according to UUNo. 32 of 2002. The method applied is normative, with statute approach and conseptual approach. Based on the analysis of legal issues using the appropriate research methods, it will be concluded that in the context of the KPI legislation, is not yet authorized to oversee new digital media, so a revision is needed especially regarding broadcasting concepts, bearing in mind that monitoring of digital media has become an important matter to pay attention to.

Keywords: surveillance; Indonesian Broadcasting Commission; digital media 


\section{PENDAHULUAN}

Salah satu alat yang berfungsi untuk menyalurkan pesan atau informasi adalah media. Agar dapat melaksanakan fungsi yang benar, maka media harus menjalankan regulasi secara profesional. Saat ini mengenai penyiaran telah diatur dalam peraturan Undang-Undang Nomor 32 Tahun 2002 tentang Penyiaran (selanjutnya disebut UU No. 32 Tahun 2002).

Definisi penyiaraan menurut UU Penyiaraan adalah suatu kegiatan pemancarluasan dalam hal siaran melalui sarana pemancaran atau sarana transmisi laut, darat atau di antariksa yang menggunakan spektrum frekuensi radio melalui kabel, udara atau media lainnya agar dapat diterima secara bersamaan dan serentak oleh masyarakat dengan perangkat penerima siaraan. Televisi dan radio adalah media penyiaran. Definisi penyiaran radio adalah media komunikasi yang dapat didengar oleh massa yang menyampaikan informasi dan gagasan secara terbuka di depan umum dalam bentuk suara, yang berisi program yang berkesinambungan dan teratur. Sedangkan penyiaran televisi adalah media komunikasi yang dapat dipandang dan didengar oleh massa atau masyarakat umum, yang menyampaikan informasi dan gagasan secara terbuka maupun secara tertutup, yang berisi program yang berkesinambungan dan teratur. ${ }^{1}$

Media digital baru yang beragam dan bermunculan saat ini di Indonesia menambah pekerjaan bagi Komisi Penyiaraan Indonesia (selanjutnya disebut KPI). Hal tersebut tidak dapat dianggap sepele, karena adanya media digital baru yang beragam membawa pengaruh bagi masyarakat baik pengaruh positif dan pengaruh negatif. Media digital baru tersebut dapat mengambil alih keberadaan media konvensional yang sudah ada pada saat ini yaitu televisi dan radio. Media digital baru tersebut antara lain: Youtube, Facebook, Instagram, Netflix dan lain sebagainya.

Kehadiran internet menciptakan satu paradigma baru mengenai proses penyampaian informasi dan pesan. Dari segi distribusi, terdapat perbedaan proses distribusi yang terjadi akibat pergeseran media konvensional seperti televisi atau radio ke media baru

${ }^{1}$ Muhammad Anshar Akil. (2014). "Regulasi Media DiIndonesia (Tinjauan UU Pers dan UU Penyiaran". Jurnal Dakwah Tabligh. 15 (2), h. 141. internet. Pada media konvensional televisi dan radio, konten didistribusikan menggunakan gelombang terestrial atau kabel/satelit secara searah, dari stasiun televisi ke masyarakat luas.

Komisi Penyiaraan Indonesia akhir-akhir ini sering melakukan kegiatan yang dapat mengedukasi masyarakat umum dengan tujuan agar masyarakt dapat memiliki kemampuan dalam mengkaji dan menelaah informasi-informasi yang diterima. Salah satu kegiatan KPI untuk mengedukasi masyarakat adalah dengan adanya literasi media, yang bertujuan agar masyarakat mengetahui dan memahami tentang keberadaan lembaga Komisi Penyiaran Indonesia dan Komisi Penyiaran Indonesia Daerah. Kegiatan ini dapat juga dimaknai sebagai gerakan sadar media yang dibuat untuk mengawasi individu terhadap media yang digunakan masyarakat untuk menerima dan mengirim berita dan pesan.

Salah satu lembaga independen yang merupakan organ lapis kedua dibentuk oleh UU di Indonesia yang kedudukannya setingkat dengan lembaga negara lainnya dan berfungsi sebagai regulator di bidang penyiaraan di Indonesia yaitu Komisi Penyiaraan Indonesia. Dibentuknya lembaga independen salah satu latar belakang dan alasannya yaitu terdapat adanya dinamika di masyarakat dalam mewujudkan suatu demokratisasi, hal tersebut dampak dari kurang percayanya masyarakat terhadap lembaga yang telah ada, di samping itu karena dengan adanya semangat keterbukaan di masyarakat sebagai sarana terciptanya hubungan yang harmonis antara masyarakat terutama masyarakat menengah dan kecil dengan pemerintah. Salah satu tugas Komisi Penyiaraan Indonesia adalah untuk mewujudkan dan meningkatkan pelayanan untuk publik yang bebas dari campur tangan politik. ${ }^{2}$

Undang-Undang tentang Penyiaran di Indonesia telah mengalami perubahan. Pengaturan tentang penyiaraan pertama di atur ke dalam Undang-Undang Nomor 24 Tahun 1997 tentang Penyiaran (selanjutnya disebut UU No. 24 Tahun 1997), kemudian UU No. 24 Tahun 1997 diubah dan dicabut menjadi Undang-Undang Penyiaran terbaru yaitu UndangUndang Nomor 32 Tahun 2002 tentang Penyiaraan.

${ }^{2}$ Irzha Friskanov. (2016). "Kedudukan dan Kewenangan Komisi Penyiaran Indonesia Daerah (KPID) atas Hak Publik dalam Penyelenggaraan Penyiaran di Provinsi Sulawesi Tengah". Lex Renaissance, 1(1), h. 76-91. 
Kedua peraturan tersebut terdapat perbedaan prinsip. UU No. 32 Tahun 2002 kental akan nuansa demokratisnya dibanding dengan UU No. 24 Tahun 1997 tentang Penyiaraan. ${ }^{3}$ Hal tersebut dapat dilihat dalam Pasal 7 ayat (1) UU No. 24 Tahun 2007 yang menyatakan bahwa "Penyiaran dikuasai oleh Negara yang pembinaan dan pengendaliannya dilakukan oleh Pemerintah". Hal tersebut menunjukan bahwa pada masa itu penyiaran adalah merupakan suatu instrumen kekuasaan yang digunakan sematamata bagi kepentingan pemerintah. Disisi lain UU No. 32 Tahun 2002 dalam Pasal 6 ayat (1) yang intinya menerangkan bahwa dalam hal penyiaraan diselenggarakan ke dalam satu sistem penyiaraan nasional. Sedangkan ayat (2) Pasal 6 menerangkan bahwa sebagaimana yang dimaksud dalam ayat (1) di atas bahwa dalam sistem penyiaraan nasional yang menguasai spektrum frekuensi radio yang digunakan dalam penyelenggaraan suatu penyiaraan guna sebesar-besarnya untuk kemakmuran rakyat. ${ }^{4}$

Adanya Undang-Undang Penyiaran terbaru yaitu UU No. 32 Tahun 2002 terdapat perubahan paradigma saat ini lembaga penyiaraan tidak lagi mengendalikan penyiaraan. Peran negara saat ini telah dibatasi oleh Undang-Undang Penyiaran karena dinilai terlalu besar terhadap media penyiaraan. Kebebasan berpendapat yang diatur dalam Undang-Undang Dasar Tahun 1945 dianggap yang mempengaruhi adanya perubahan paradigma suatu tatanan demokrasi. Berdasarkan asas demokrasi, masyarakat diberikan peran yang lebih besar untuk dapat menggerakan dan mengatur ranah penyiaraan.

UU No. 32 Tahun 2002 mengamanatkan adanya sebuah lembaga yang mandiri tidak terpengaruh oleh pihak manapun yang bernama Komisi Penyiaran Indonesia dan lembaga ini berfungsi sebagai lembaga pengawas penyiaran. Komisi Penyiaran Indonesia terbentuk melalaui undang-undang dan memiliki tanggung jawab kepada DPR RI sebagai wakil rakyat. Maksud hal tersebut bahwa Komisi Penyiaran Indonesia dalam melakukan tugas, fungsi dan wewenangnya tanpa adanya tekanan serta campur tangan dari pemerintah. UU No. 24 Tahun

\footnotetext{
${ }^{3}$ Hidajanto Djamal dan Andi Fachruddin. (2011). DasarDasar Penyiaran: Sejarah, Organisasi, Operasional, dan Regulasi. Jakarta: Kencana, h. 271.

${ }^{4}$ Denico Dolly. (2015). "Upaya Penguatan Kelembagaan Komisi Penyiaran Indonesia Dalam Perspektif Hukum”. Negara Hukum, 6 (2), h. 149-150.
}

1997 tentang penyiaraan menunjukan tugas sebagai regulator yang diserahkan kepada Pemerintah masalah penyiaraan tidak berjalan dengan baik. Hal tersebut dapat dilihat dan dibuktikan dengan adanya beberapa peraturan pelaksana UU No. 24 Tahun 1997 tentang Penyiaraan yang tidak dibuat dan dikeluarkan oleh pemerintah.

Disamping itu terdapat beberapa pendapat bahwa yang mempunyai otoritas terhadap isi siaran yang disiarkan oleh lembaga penyiaran adalah pemerintah. ${ }^{5}$ Saat itu Departemen Penerangan menjadikan lembaga penyiaran sebagai alat propaganda. Oleh karena itu melalui UU Penyiaran ada perubahan paradigma dan juga perubahan model penyelenggara penyiaran dimana sebagai regulator bidang penyiaran yang diamanatkan kepada KPI.

UU No. 32 Tahun 2002 Pasal 1 angka 13 menerangkan bahwa KPI yaitu lembaga yang memiliki sifat independen dari lembaga negara yang berkedudukan tidak hanya di pusat tetapi di daerah juga yang memiliki tugas dan wewenang yang telah diatur dalam peraturan ini sebagai wujud peran serta masyarakat dalam hal penyiaraan. Dalam Pasal 7 ayat (2) dalam peraturan ini menerangkan bahwa KPI adalah lembaga yang mengatur di bidang penyiaraan yang bersifat independen. Keberadaan KPI sebagai lembaga yang bertugas untuk melakukan pengawasan terhadap kegiatan penyiaran diharapkan memberikan kepastian hukum kepada masyarakat dalam hal penyiaran. Hal ini dilakukan agar masyarakat dapat memperoleh konten siaran yang bermanfaat.

Komisi Penyiaran Indonesia sebagai representasi masyarakat diharapkan dapat menjamin hak masyarakat untuk mendapatkan isi siaran atau konten dan juga informasi yang adil dan bebas serta agar dapat melibatkan masyarakat guna mengelola lembagalembaga dan juga dapat menjamin kemandirian lembaga penyiaran di bidang penyiaraan. Disamping itu diharapkan Komisi Penyiaran Indonesia ke depan mewujudkan masyarakat agar mendapatkan konten yang dapat menumbuh kembangkan pendidikan serta pengetahuan masyarakat. Konten yang bermanfaat dan sehat merupakan parameter bagi Komisi

\footnotetext{
${ }^{5}$ Rhiza S. Sadjad. "Likuidasi Departemen Penerangan". www.unhas.ac.id/rhiza/arsip/makalah/likuid.rtf, diakses tanggal 22 Oktober 2015.
} 
Penyiaran Indonesia dalam menjalankan tugas, fungsi dan wewenangnya. ${ }^{6}$

Penyiaran konten yang semula disiarkan menggunakan jaringan penyiaran konvensional sebagaimana diatur dalam UU No. 32 Tahun 2002 juga mulai bermigrasi melalui jaringan internet seperti dalam hal TV berlangganan yang ditawarkan First Media atau Indohome atau kontenkonten pengulangan siaran dari televisi kemudian diunggah di platform media sosial. Sama halnya dengan tersedianya channel televisi luar negeri yang ditawarkan oleh layanan TV atau internet berlangganan. Sayangnya hukum positif Indonesia belum menjangkau konvergensi media dan situasi tersebut. $^{7}$

Sebagaimana yang telah dilansir dari berita yang bertajuk "Soal Pengawasan Konten YouTube \& Netflix, Komisi Penyiaran Indonesia Dapat Sampaikan Laporan ke Kominfo" yang diterbitkan oleh platform berita kompas.com, menyatakan isu pengawasan digital konten di Youtube dan Netflix mulai diinformasikan oleh Bapak Ketua KPI Pusat, yaitu Agung Suprio, setelah pengukuhan Komisioner Komisi Penyiaraan Indonesia periode Tahun 2019 - 2022 yaitu pada awal Agustus lalu. Agus Suprio berpendapat bahwa dalam hal controlling terhadap Youtube dan Netflix diperlukan lantaran mayoritas masyarakat saat ini telah berpindah dari media konvensional radio dan televisi. ${ }^{8}$ Adapun konsep pembatasan yang dimaksud disini adalah meliputi penyensoran dan take down (memaksa untuk menghapus konten negatif).

Menurut Pasal 36 UU No. 32 Tahun 2002, ruang lingkup konten yang dilarang dan yang berada dalam pengawasan adalah konten yang fitnah, menghasut, menyesatkan dan/atau bohong, unsur kekerasan, cabul, perjudian, penyalahgunaan narkotika dan obat terlarang. Mempertentangkan suku, agama, ras, dan antar golongan, memperolok, merendahkan, melecehkan, mengabaikan nilai-nilai

\footnotetext{
${ }^{6}$ Denico Dolly, op.cit.

7 Lintang Setianti dan Wahyudi Djafar. (2017). "Tata Kelola Konten Internet di Indonesia-Kebijakan, Praktik, dan Permasalahannya". Lembaga Studi dan Advokasi Masyarakat (ELSAM), h. 6.

8 Christoforus Ristianto. "Soal Pengawasan Konten YouTube dan Netflix, KPI Bisa Sampaikan Laporan ke Kominfo”. https:/nasional.kompas.com/read/2019/08/13/soal-pengawasankonten-youtube-dan-netflix-kpi-bisa sampaikan-laporan, all diakses pada tanggal 8 September 2019.
}

agama, martabat manusia Indonesia, atau merusak hubungan internasional.

\section{PERUMUSAN MASALAH}

Kedudukan KPI dalam ketatanegaraan Indonesia serta kewenangannya dalam pembatasan konten digital Netflix.

\section{METODE PENELITIAN}

Metode yang digunakan dalam penelitian jurnal ini yaitu yuridis normatif atau legal research dengan menggunakan pendekatan perundang-undangan (statute approach) yang mengkaji undang-undang dan peraturan yang terkait serta pendekatan konseptual (conseptual approach) yang mengkaji teori-teori dan doktrin-doktrin dari para ahli bidang penyiaran.

\section{PEMBAHASAN \\ Kedudukan KPI di Dalam Ketatanegaraan Indonesia}

Terdapat dua aspek dalam setiap sistem ketatanegaraan aspek yang pertama yang berhubungan dengan kekuasaan lembaga-lembaga negara beserta hubungannya satu sama lain diantara lembaga-lembaga negara tersebut, dan aspek yang kedua yaitu hubungan antara warga negara dengan lembaga negara. ${ }^{9}$

Lembaga negara terkadang disebut dengan istilah lain yaitu lembaga non departemen atau lembaga pemerintahan. Lembaga negara tidak hanya dibentuk berdasarkan kekuasaan yang diberi oleh UUD RI 1945 saja, akan tetapi dapat juga dibentuk berdasarkan undang-undang, dan juga ada yang didirikan berdasarkan oleh Keputusan Presiden. ${ }^{10}$ Hirarki atau tingkatan lembaga negara tergantung dari derajat pengaturannya yang berdasarkan dengan peraturan perundang-undangan yang berlaku. Organ Konstitusi ialah salah satu lembaga yang dibentuk yang berdasarkan UUD RI 1945, sedangkan Organ Undang-Undang yaitu lembaga negara yang telah dibentuk berdasarkan undang-Undang, lembaga negara yang dibentuk berdasarkan Keputusan

\footnotetext{
${ }^{9}$ Lukman Hakim. (2010). "Kedudukan Hukum Komisi Negara di Indonesia”. Malang: Setara Press, h. 42.

10 Jimly Asshiddiqie. (2006). Perkembangan dan Konsolidasi Lembaga Negara Pasca Reformasi. Jakarta: Sekretariat Jendral dan Kepaniteraan Mahkamah Konstitusi RI, h. 1 .
} 
Presiden derajat dan tingkatan lebih rendah perlakuan hukumnya terhadap pejabat yang duduk didalamnya. Begitu pula lembaga negara dibentuk yang diberi kekuasaan berdasarkan Peraturan Daerah, tentu tingkatannya lebih rendah lagi. Menurut tingkatan atau hirarki lembaga negara dibagi menjadi 3 lapis antara lain: ${ }^{11}$ tingkatan yang pertama yaitu organ lapis pertama disebut sebagai lembaga tinggi negara, dimana fungsi, nama dan kewenangannya dibentuk berdasarkan UUD 1945; tingkatan yang kedua yaitu organ lapis kedua disebut sebagai lembaga negara saja, dimana dalam lapis atau tingkatan kedua ini dimana sumber kewenangannya berasal dari UUD RI 1945, terdapat juga yang sumber kewenangannya berasal dari undang-undang, regulator atau pembentuk peraturan yang berada di bawah undangundang; dan organ lapis ketiga yaitu lembaga daerah, yaitu lembaga yang terdapat di daerah yang telah diatur dari UUD RI 1945 adalah Gubernur, DPRD Provinsi, DPRD Kota, DPRD Kabupaten, Pemerintah Daerah Provinsi, Pemerintah Daerah Kabupaten, Pemerintah Daerah Kota, Bupati, Walikota lembaga negara yang berdasarkan perintah undang-undang tersebut yaitu lembaga independen, lembaga yang dapat berdiri sendiri dengan tanpa campur tangan oleh pemerintah yaitu lembaga independen.

Lembaga negara independen sekilas memang menyerupai organisasi non pemerintah (non governmental organization (NGO)) atau yang biasa disebut lembaga swadaya masyarakat karena lembaga ini terdapat di luar sistem pemerintahan eksekutif. Tetapi, lembaga ini keberadaanya memiliki sifat publik dan juga memiliki sumber pendanaannya yang berasal dari publik juga, yang memiliki tujuan guna kepentingan publik, lembaga ini tidak dapat disebut lembaga non pemerintahan (NGO) dalam arti sebenarnya.

Pengesahan atau legitimasi dibentuknya lembaga negara independen mendapatkan respon baik setelah perubahan Undang-Undang Dasar 1945. Dengan memiliki konstitusi baru yang telah diamandemen ini cukup menyediakan tempat yang lebih luas guna pembentukan dan perkebangan lembaga negara yang dibentuk oleh Presiden dan DPR RI yang berdasarkan undang-undang. Pembentukan

11 Gokma Toni Parlindungan S. (2013). “Tinjauan Umum Pembagaian Kekuasaan Dalam Hukum Tata Negara di Indonesia”. Jurnal Advokasi, 4(2), h. 21. lembaga negara bantu hasil amandemen tersebut kini menjadi bagian dari politik hukum negara untuk menguatkan dan melengkapi upaya pemerintah untuk mewujudkan cita-cita bangsa. Yang artinya, amandemen ke 4 Undang-Undang Dasar 1945 memberikan begitu banyak ruang dan dasar hukum mengenai independensi lembaga-lembaga negara yang hadir setelah amandemen ini. ${ }^{12}$

Perkembangannya di Indonesia yang kini sudah memiliki dan melahirkan lembaga-lembaga negara baru yang bersifat independen ini tidak lepas mengingat Indonesia telah Indonesia mengalami masa perubahan atau transisi, juga mengalami fasefase penting di masa itu. Dengan lahir dan hadirnya lembaga-lembaga negara penunjang (state auxiliary bodies) yang bersifat independen, KPI (Komisi Penyiaran Indonesia) turut andil membantu proses transisi.

Adapun ditinjau dari segi kuantitas, lembaga negara yang indepen tidak akan menjadi masalah apabila mengenai keberadaan dan pembentukannya tercermin prinsip-prinsip antara lain sebagai berikut: ${ }^{13}$

1. Prinsip konstitusionalisme

Konstitusionalisme adalah suatu konsep atau gagasan yang berpendapat bahwa perlu adanya pembatasan terhadap kewenangan penyelengara negara, dalam hal ini adalah pemerintah. Prinsip ini bertujuan agar penyelenggaraan negara tidak sewenang-wenang. Dengan pembatasan yang sedemikian, lembaga-lembaga negara dapat membantu menunjukkan eksistensinya agar hakhak dasar warga negara semakin terjamin dan demokrasi dapat terjaga.

2. Prinsip checks and balances

Prinsip checks and balances merupakan prinsip ketatanegaraan yang sejatinya menghendaki agar tiap-tiap kekuasaan legislatif, eksekutif, dan yudikatif sama-sama sederajat dan saling mengontrol satu sama lain.

3. Prinsip integrasi

Selain daripada memiliki fungsi dan kewenangan yang jelas, konsep kelembagaan negara juga harus membentuk suatu kesatuan yang turut berproses dalam melaksanakan fungsinya. Ketiadaan sistem yang integral dapat

12 Ibid., h. 6.

${ }^{13}$ Ni'matul Huda. (2005). Hukum Tata Negara Indonesia. Jakarta: PT. Raja Grafindo Persada, h. 67. 
mengakibatkan kewenangan antar lembaga menjadi tumpang-tindih, dan menimbulkan tidak efektifnya penyelenggaraan pemerintahan.

4. Prinsip kemanfaatan bagi masyarakat

Seyogyanya pembentukan lembaga negara banru diperuntukkan agar dapat mengoptimalkan kesejahteraan warga negaranya serta menjamin hak-hak dasar warga Negara.

Perlu diketahui bahwa perihal kedudukan lembaga KPI, ditinjau dari segi hukum dan politik, KPI berada pada posisi dan didudukkan sebagai lembaga bantu negara atau state auxialiary bodies. ${ }^{14}$ Sebagaimana lembaga negara bantu yang lain, yang sekiranya dapat disetarakan dengan kedudukan KPI, antara lain lembaga Komisi Nasional Hak Asasi Manusia, Komisi Perlindungan Anak Indonesia, Komisi Anti Kekerasan Terhadap Perempuan, Komisi Pemberantasan Korupsi, dan lembaga negara bantu yang independen lainnya.

Agus Sudibyo menyatakan bahwa setidaknya terdapat empat alasan di balik pembentukan KPI sebagai lembaga negara bantu yang independen antara lain:15 (1) domain publik, (2) sebagai ujud kontrol kekuasaan, (3) terdapat banyak dan variatif pemilik konten siaran dan substansi konten yang semakin berkembang, (4) desentralisasi dunia penyiaran.

Perlindungan hak asasi manusia dan pemajuan kesejahteraan umum merupakan tujuan bernegara yang justru paling sesuai dengan visi misi masyarakat yang kini sudah tidak lagi primitif. Di lain sisi, negara dalam hal ini pemerintah senantiasa memerangi hukum besi kekuasaan yang sudah sejak lama terjadi, yaitu power tends to corrupt, absolute power corrupts absolutely. Mengatasi paradigma tersebut, negara melalui pemerintah telah berupaya mengembangkan berbagai sistem ketatanegaraan, baik dari sisi teoritis terlebih lagi dari segi praktis. Sebagai salah satu prinsip sekaligus sistem yang dimaksudkan adalah dengan diterapkannya prinsip check and balances.

${ }^{14}$ Zainal Arifin Mochtar dan Iwan Satriawan. (2008). "Sistem Seleksi Komisioner State Auxiliary Bodies (Suatu Catatan Analisis Komparatif)". Jurnal Konstitusi, 1(1), h. 86.

${ }^{15}$ Agus Sudibyo. (2010). "Ada Apa dengan PP Penyiaran”, 2005 dalam Rubric Opini Kompas tanggal 24 Maret 2005, dalam Agus Ngadino, "Pergeseran Relasi Negara dan Media Massa Dalam Kerangka Demokrasi”. Jurnal Simbur Cahaya, XV(43), h. 113.
Adapun prinsip check and balances ini dapat ditelaah melalui teori pemisahan kekuasaan.

Dengan mengamati Undang-Undang No. 32 Tahun 2002 tentang Penyiaran dengan menggunakan pendekatan Hukum Tata Negara (staatsrectelijke) yang memungkinkan pembentukan independent state body di luar struktur pemerintahan eksekutif, legislatif, ataupun yudikatif berikut juga mengenai tugas, fungsi, wewenang dan kewajiban yang diberikan secara langsung oleh undang-undang. Konsep independent state body ini sebenarnya bukan hal baru bagi Indonesia. Saat ini sudah cukup kita ketahui sudah cukup banyak lembaga-lembaga yang bersifat independen dan mempunyai fungsi campuran antara sifat legislatif,eksekutif, dan/atau sekaligus yudikatif, yang eksistensinya didistribusikan melalui undang-undang. ${ }^{16}$

\section{Kewenangan KPI dalam Membatasi Konten Digital Media Netfilx Menurut Undang-Undang Penyiaraan}

Sebagaimana yang diamanatkan oleh UU No. 32 Tahun 2002, KPI diberi wewenang sekaligus fungsi untuk menyusun dan mengawasi berbagai peraturan terkait penyiaran dengan mengsinergikan lembaga penyiaran dengan pemerintah dan masyarakat. Pengaturan ini juga meliputi seluruh proses kegiatan penyiaran, dimulai dari tahap pendirian, operasionalisasi, pertanggungjawaban, dan evaluasi.

Berdasarkan Pasal 8 ayat (2) UU No. 32 Tahun 2002, dalam menjalankan fungsinya, KPI mempunyai wewenang:

1. Menetapkan standar program siaran;

2. Menyusun peraturan dan menetapkan pedoman perilaku penyiaran (diusulkan oleh asosiasi/ masyarakat penyiaran kepada KPI);

3. Mengawasi pelaksanaan peraturan dan pedoman perilaku penyiaran serta standar program siaran;

4. Memberikan sanksi terhadap pelanggaran peraturan dan pedoman perilaku penyiaran serta standar program siaran;

5. Melakukan koordinasi dan/atau kerjasama dengan Pemerintah, lembaga penyiaran, dan masyarakat.

Sedangkan dalam Peraturan Komisi Indonesia Nomor: 01/P/KPI/07/2014 tentang Kelembagaan

${ }^{16}$ Jimly Asshiddiqie. (2006). Pengantar Ilmu Hukum Tata Negara Jilid 2. Jakarta: Konpres, h. 24. 
Komisi Penyiaran Indonesia Pasal 3 ayat (2) menyebutkan bahwa "dalam menjalankan fungsinya sebagaimana dimaksud dalam ayat (1) Pasal ini, KPI mempunyai wewenang:

a. Menetapkan SPS;

b. Menyusun peraturan dan menetapkan P3;

c. Mengawasi pelaksanaan peraturan dan P3 serta SPS;

d. Memberikan sanksi terhadap pelanggaran peraturan dan P3 serta SPS;

e. Melakukan koordinasi dan/atau kerjasama dengan Pemerintah, lembaga penyiaran, dan masyarakat.

Salah satu wewenang KPI berdasarkan UU Penyiaran adalah mengawasi pelaksanaan peraturan dan pedoman perilaku penyiaran serta standar program siaran. Batasan mengenai objek wewenangwewenang KPI di atas sendiri telah diatur cukup jelas di dalam Pasal 13 UU No. 32 Tahun 2002. Hal ini tersurat dalam pengaturan mengenai jasa penyiaran, yang mana jasa penyiaran yang dimaksud terdiri atas jasa penyiaran radio dan jasa penyiaran televisi. Mengenai penyelenggaranya, penyelenggaraan, jasa penyiaran dapat diselenggarakan antara lain oleh lembaga penyiaran publik, lembaga penyiaran swasta, lembaga penyiaran komunitas, dan lembaga penyiaran berlangganan.

Dengan demikian, kewenangan kewenangan KPI sebagai penyelenggara penyiaran sejatinya terbatas pada konten radio dan televisi, serta lembaga penyiarannya. Dengan kata lain, KPI pada dasarnya tidak berwenang untuk mengawasi media digital baru antara lain: Youtube, Facebook, Instagram, Netflix, dan lain sebagainya.

Isu bahwa akan ada perluasan pengawasan terhadap wewenang KPI untuk mengawasi konten di media baru, KPI berkehendak untuk mengupayakan aturan yang nantinya menjadi pedoman untuk menambah obyek pengawasan konten digital dari media yang baru-baru ini digandrungi masyarakat banyak seperti YouTube, Facebook, Netflix, dan media sejenis. Maksud ini disampaikan Ketua KPI Pusat Agung Suprio seusai acara pengukuhan komisioner periode 2019-2022 yang diselenggarakan oleh Kementrian Komunikasi dan Informatika di Jakarta pada tanggal 06 Agustus 2019. Pernyataan tersebut dijelaskan dengan pelbagai alasan, termasuk agar konten-konten yang berada di media digital selain layak ditonton, juga bersifat edukatif dan memiliki pesan moral yang sesuai dengan nilainilai luhur dari Pancasila. Hal ini dipandang oleh KPI perlu dilakukan karena saat ini telah terjadi pergeseran kebiasaan dan kebutuhan masyarakat yang saat ini lebih condong mengakses media-media digital baru seperti YouTube, Netflix, Facebook, atau dibanding media konvensional seperti televisi dan radio. ${ }^{17}$

Dengan menelaah UU No. 32 Tahun 2002 ternyata belum ada kewenangan KPI untuk mengawasi konten di platform streaming seperti Netflix, YouTube, dan lain sebagainya, mengingat media ini adalah media digital yang termasuk baru dan peminatnya belum banyak pada waktu sebelum pembentukan undang-undang penyiaran yang terbaru. Sehingga langkah awal yang selanjutnya akan diambil oleh KPI adalah KPI berencana akan merevisi UndangUndang tentang Penyiaran. Pengawasan tersebut dilakukan agar konten-konten yang berada di media digital selain layak ditonton, juga bersifat eduktaif dan memiliki pesan moral yang sesuai dengan nilainilai luhur dari Pancasila. Alasan lain dari maksud KPI ini adalah karena menimbang sebagian besar masyarakat sudah beralih dari media konvensional televisi dan radio dan lebih condong mengakses media atau konten pada platfrom streaming. KPI sendiri mengupayakan agar penambahan wewenang tersebut dapat masuk dalam revisi UU No. 32 Tahun 2002.

Dalam Peraturan Komisi Indonesia Nomor: 01/P/KPI/07/2014 tentang Kelembagaan Komisi Penyiaran Indonesia pada Pasal 4 ayat (1) terdapat 3 Pembidang KPI antara lain:

a. Bidang Pengelolaan Struktur dan Sistem Penyiaran;

b. Bidang Pengawasan Isi Siaran; dan

c. Bidang Kelembagaan.

Dalam melaksanakan fungsi, wewenang, tugas, dan kewajiban sebagaimana dimaksud dalam ayat (1) huruf $b$ Pasal ini, Bidang Pengawasan isi Penyiaran menyelenggarakan koordinasi, mengawasi, dan mengevaluasi program dan kegiatan:

${ }^{17}$ M. Agus Yozami. "KPI Ingin Awasi Konten Digital, Kominfo: Belum Ada Aturannya". dikutip: https://www. hukumonline.com/berita/baca/lt5d5260a5e791a/kpi-inginawasi-konten-digital--kominfo--belum-ada-aturannya/, tanggal 12 Oktober 2019. 
a. Penyusunan peraturan dan keputusan KPI yang menyangkut isi penyiaran;

b. Pengawasan pelaksanaan dan penegakan peraturan KPI menyangkut isi penyiaran;

c. Pemeliharaan tatanan informasi nasional yang adil, merata, dan seimbang; dan

d. Menampung, meneliti, dan menindaklanjuti aduan, sanggahan, kritik, dan apresiasi masyarakat terhadap penyelenggaraan penyiaran.

Berdasarkan Pasal 3 Undang-Undang No. 32 Tahun 2002 tentang Penyiaran, menyebutkan bahwa: "Penyiaran diselenggarakan dengan tujuan untuk memperkukuh integrasi nasional, terbinanya watak dan jati diri bangsa yang beriman dan bertakwa, mencerdaskan kehidupan bangsa, memajukan kesejahteraan umum, dalam rangka membangun masyarakat yang mandiri, demokratis, adil dan sejahtera, serta menumbuhkan industri penyiaran Indonesia."

Sebagai lembaga-lembaga penyiaran yang merupakan media komunikasi massa dan mempunyai peran penting dalam kehidupan bernegara baik disisi sosial, budaya, politik, sampai ekonomi. Lembagalembaga penyiaran yang telah diberi kebebasan dan tanggung jawab dalam menjalankan fungsinya sebagai media informasi, pendidikan, hiburan, serta kontrol dan perekat sosial, tetap diharapkan dapat memberikan dampak positif di masyarakat dan memberikan nilai-nilai edukasi bagi masyarakat.

Sebagaimana yang dimaksud dengan definisi Penyiaran dalam Pasal 6 UU No. 32 Tahun 2002 tentang Penyiaran, yang mana penyiaran yang diterima oleh masyarakat secara bersamaan, serentak dan bebas, berpengaruh besar dalam pembentukan pendapat, pola pikir, sikap, dan perilaku khalayak, maka dengan dampak yang sedemikian rupa, sudah seyogyanya penyelenggara penyiaran turut andil berdalam menjaga nilai moral, tata susila, budaya, kepribadian dan kesatuan bangsa yang berlandaskan Pancasila. Seiring dengan tugas lembaga KPI dalam mengawasi konten-konten yang disebarluaskan di masyarakat baik Televisi dan Radio, dan juga konten dalam media digital baru antara lain: YouTube, Netflix, Facebook atau media sejenis dengan catatan akan merevisi UU tentang Penyiaran dalam hal kewenangan KPI untuk mengawasi isi siaran dalam media digital baru.
Dengan adanya wacana penambahan wewenang pengawasan KPI terhadap media baru yang salah satunya adalah media Netflix, penulis berpendapat bahwa hal tersebut tidak urgent untuk dilakukan. Karena media Netflix tidak memenuhi unsur karakteristik penyiaran yang telah di atur dalam UU Penyiaran, lebih baik mengawasi konten yang ada dalam stasiun televisi yang disiarkan serentak dan bersamaan oleh masyarakat.

Media penyiaran yang sebenarnya memiliki karakteristik yang unik atau spesifik dibandingkan dengan media cetak atau media massa yang lainnya. Dikatakan unik karena dengan media penyiaran ini, informasi dapat disalurkan serta disebarluaskankan untuk diterima khalayak secara langsung atau biasa disebut dengan real time atau live. Seluruh kejadian atau peristiwa yang secara langsung pada waktu bersamaan didengar/dilihat oleh pendengar/pemirsa dengan cakupan populasi yang sangat luas dan efektif, namun terhadap informasi yang disampaikan oleh media penyiaran yang sudah langsung berlalu, tidak dapat berulang lagi kecuali memang diberi kebijakan untuk disiarkan ulang. Sementara pada media cetak, informasi yang diberikan masih dapat dibaca kembali, dimana dan kapan saja, dengan cakupan populasinya relatif lebih sempit. ${ }^{18}$

Berdasarkan karakteristik media penyiaraan disebutkan di atas media Netflix tidak memenuhi karakteristik media penyiaraan. Karakteristik media netflix yang sejatinya adalah layanan berlangganan berbasis streaming, yang mana ditawarkan secara online dengan program film dan televisi, termasuk beberapa program yang dibuat oleh Netflix sendiri. Karena tidak terpenuhinya karakteristik Netflix dengan konsep penyiaraan yang terdapat dalam UU Penyiaraan hal tersebut berarti KPI tidak memiliki kewenangan untuk melakukan pengawasan pada media Netflix.

Hal yang seharusnya diawasi oleh KPI adalah siaran-siaran dari tv swasta dan tv lokal, yang menyajikan siaran tv yang kurang mengedukasi, permasalahan pribadi artis yang disajikan di talk show, reality show yang penuh sandiwara dan sensasional, permasalahan fiktif dengan adeganadegan konyol yang tidak mendidik, komedi dengan guyonan kasar dan konten negatif lainnya. Salah satu contohnya adalah tayangan Pesbukers,

${ }^{18}$ Hidajanto Djamal dan Andi Fachruddin, op.cit., h. 59. 
yang melakukan banyak pelanggaran. Dalam setiap episode ditemukan sedikitnya tiga kategori pelanggaran, yakni:

a) Pelanggaran terhadap norma kesopanan dan kesusilaan,

b) Pelanggaran terhadap pembatasan adegan kekerasan, serta

c) Pelanggaran terhadap adegan kekerasan, ungkapan kasar, dan makian. ${ }^{19}$

Adapun tayangan pesbukers telah diberhentikan sejak 9 Desember 2019 karena KPI menganggap tayangan tersebut mengabaikan aturan Pedoman Perilaku Penyiaran (P3) dan pelanggaran terhadap Standar Program Siaran (SPS) KPI tahun 2012.

Dalam hal ini KPI telah melakukan tugas sesuai dengan tugas dan kewenangan dalam rangka melakukan pengawasan dan/atau pembatasan terhadap siaran di media konvensional (televisi). Namun apabila KPI hendak melakukan pembatasan pada konten media di Netflix, maka hal tersebut sudah di luar dari tugas dan kewenangannya serta tidak sesuai dengan konsep penyiaran berdasarkan UU No. 32 Tahun 2002 tentang Penyiaran.

\section{PENUTUP}

\section{Kesimpulan}

Berdasarkan analisis dan pembahasan di atas, penulis menyimpulkan bahwa dalam rangka menjalankan fungsinya, KPI sebagai lembaga independen (state auxialiary bodies) yang memiliki kewenangan untuk menyusun serta mengawasi berbagai peraturan mengenai penyiaran yang menghubungkan antara lembaga penyiaran, pemerintah dan masyarakat.

Rencana dari KPI yang hendak melakukan pembatasan pada konten media di Netflix, sudah di luar dari tugas dan kewenangannya serta tidak lagi sesuai dengan konsep penyiaran berdasarkan UU No. 32 Tahun 2002 tentang Penyiaran. Konsep penyiaran yang dimaksud adalah pemancarluasan siaran melalui sarana pemancaran dan/atau sarana transmisi di darat, di laut atau di antariksa dengan menggunakan ilegal frekuensi radio melalui udara, kabel, dan/atau media lainnya. Sedangkan Netflix adalah layanan berlangganan berbasis streaming,

${ }^{19}$ Rifki Nur Pratiwi, Turnomo Rahardjo, dan Tandiyo Pradekso. (2013). "Penerapan Standar Program Siaran Dalam Tayangan Pesbukers". Jurnal Interaksi Online, Vol. 1 No. 3, h. 1. yang mana ditawarkan secara online dengan program film dan televisi, termasuk beberapa program yang dibuat oleh Netflix sendiri. Karena tidak terpenuhinya karakteristik Netflix dengan konsep penyiaraan yang terdapat dalam UU Penyiaraan hal tersebut berarti KPI tidak memiliki kewenangan untuk melakukan pengawasan pada media Netflix.

\section{Rekomendasi}

Sebaiknya KPI membenahi dan mengawasi terlebih dahulu program siaran yang terdapat di stasiun televisi, karena program yang ada di stasiun televisi diterima secara serentak oleh masyarakat luas. Perlu adanya revisi konsep penyiaran dan penambahan wewenang KPI agar dapat mengawasi media digital baru salah satunya Netflix.

\section{DAFTAR PUSTAKA}

\section{Peraturan Perundang-undangan:}

Undang-Undang Dasar Negara Republik Indonesia Tahun 1945

Undang-Undang Nomor 24 Tahun 1997 tentang Penyiaran, Lembaran Negara Republik Indonesia Tahun 1997 Nomor 72, Tambahan Lembaran Negara Republik Indonesia Nomor 3701.

Undang-Undang Nomor 32 Tahun 2002 tentang Penyiaran, Lembaran Negara Republik Indonesia Tahun 2002 Nomor 139, Tambahan Lembaran Negara Republik Indonesia Tahun 2002 Nomor 4252.

Peraturan Komisi Indonesia Nomor: 01/P/ KPI/07/2014 tentang Kelembagaan Komisi Penyiaran Indonesia

\section{Buku:}

Hidajanto Djamal dan Andi Fachruddin. (2011). Dasar-Dasar Penyiaran: Sejarah, Organisasi, Operasional, Dan Regulasi, Jakarta: Kencana.

Jimly Asshiddiqie. (2006). Perkembangan dan Konsolidasi Lembaga Negara Pasca Reformasi. Jakarta: Sekretariat Jendral dan Kepaniteraan Mahkamah Konstitusi RI.

Jimly Asshiddiqie. (2006). Pengantar Ilmu Hukum Tata Negara Jilid 2. Jakarta: Konpres.

Lukman Hakim. (2010). Kedudukan Hukum Komisi Negara di Indonesia. Malang: Setara Press.

Ni'matul Huda. (2005). Hukum Tata Negara Indonesia. Jakarta: PT. Raja Grafindo Persada. 
Peter Mahmud Marzuki. (2016). Penelitian Hukum. Edisi Revisi Cetakan ke-12. Jakarta: Kencana.

\section{Jurnal:}

Agus Sudibyo. (2010). “Ada Apa dengan PP Penyiaran, 2005 dalam Rubric Opini. Kompas tanggal 24 Maret 2005, dalam Agus Ngadino, "Pergeseran Relasi Negara Dan Media Massa Dalam Kerangka Demokrasi”, Jurnal Simbur Cahaya, XV(43).

Denico Dolly. (2015). "Upaya Penguatan Kelembagaan Komisi Penyiaran Indonesia Dalam Perspektif Hukum", Jurnal Hukum: Negara Hukum, 6(2).

Gokma Toni Parlindungan S. (2013). "Tinjauan Umum Pembagaian Kekuasaan Dalam Hukum Tata Negara di Indonesia”. Jurnal Advokasi, 4(2).

Irzha Friskanov. (2016). "Kedudukan dan Kewenangan Komisi Penyiaran Indonesia Daerah (KPID) atas Hak Publik dalam Penyelenggaraan Penyiaran di Provinsi Sulawesi Tengah". Jurnal Hukum: Lex Renaissance, 1(1).

Lintang Setianti dan Wahyudi Djafar. (2017). "Tata Kelola Konten Internet di Indonesia-Kebijakan, Praktik, dan Permasalahannya". Lembaga Studi dan Advokasi Masyarakat (ELSAM).
Muhammad Anshar Akil. (2014). "Regulasi Media Di Indonesia (Tinjauan UU Pers dan UU Penyiaran". Jurnal Dakwah Tabligh, 15(2).

Rifki Nur Pratiwi, Turnomo Rahardjo, dan Tandiyo Pradekso. (2013). "Penerapan Standar Program Siaran Dalam Tayangan Pesbukers". Jurnal Interaksi Online, Vol. 1 No. 3.

Zainal Arifin Mochtar dan Iwan Satriawan. (2008). "Sistem Seleksi Komisioner State Auxiliary Bodies (Suatu Catatan Analisis Komparatif)". Jurnal Konstitusi, 1(1).

\section{Website:}

Christoforus Ristianto. "Soal Pengawasan Konten YouTube dan Netflix, KPI Bisa Sampaikan Laporan ke Kominfo". https://nasional. kompas.com/read/2019/08/13/05525901/soalpengawasan-konten-youtube-dan-netflix-kpibisa-sampaikan-laporan-ke?page=all

M. Agus Yozami. "KPI Ingin Awasi Konten Digital, Kominfo: Belum Ada Aturannya". dikutip:https://www.hukumonline.com/berita/ baca/lt5d5260a5e791a/kpi-ingin-awasi-kontendigital--kominfo--belum-ada-aturannya/s

Rhiza S. Sadjad. "Likuidasi Departemen Penerangan". www.unhas.ac.id/rhiza/arsip/ makalah/likuid.rtf 